\title{
New Insights into the Generation of CD4 Memory May Shape Future Vaccine Strategies for Influenza
}

\author{
Priyadharshini Devarajan, Bianca Bautista, Allen M. Vong, Karl Kai McKinstry ${ }^{\dagger}$, \\ Tara M. Strutt ${ }^{\dagger}$ and Susan L. Swain*
}

Department of Pathology, University of Massachusetts Medical School, Worcester, MA, USA

OPEN ACCESS

Edited by:

Paul G. Thomas,

St. Jude Children's Research

Hospital, USA

Reviewed by:

Annette Oxenius,

ETH Zurich, Switzerland

Joshua Farber,

National Institutes of Allergy and

Infectious Diseases, USA

*Correspondence:

Susan L. Swain

susan.swain@umassmed.edu

tPresent address:

Karl Kai McKinstry and Tara M. Strutt,

Division of Infectious Disease,

Burnett School

of Biomedical Sciences,

University of Central Florida,

Orlando, FL, USA

Specialty section:

This article was submitted to Immunological Memory,

a section of the journal

Frontiers in Immunology

Received: 12 January 2016

Accepted: 28 March 2016

Published: 11 April 2016

Citation:

Devarajan P, Bautista B, Vong AM,

McKinstry KK, Strutt TM and

Swain SL (2016) New Insights into

the Generation of CD4 Memory

May Shape Future Vaccine

Strategies for Influenza.

Front. Immunol. 7:136.

doi: 10.3389/fimmu.2016.00136
Influenza viral evolution presents a formidable challenge to vaccination due to the virus' ability to rapidly mutate to evade immune responses. Live influenza infections generate large and diverse CD4 effector T cell responses that yield highly protective, long-lasting CD4 T cell memory that can target conserved viral epitopes. We review advances in our understanding of mechanisms involved in generating CD4 T cell responses against the influenza A virus (IAV), focusing on specialized follicular helper $\left(T_{F H}\right)$ and CD4 cytotoxic (ThCTL) effector subsets and on CD4 T cell memory. We also discuss two recent findings in context of enhancing vaccine responses. First, helper T cells require priming with APC secreting high levels of IL-6. Second, the transition of IAV-generated effectors to memory depends on IL-2, costimulation and antigen signals, just before effectors reach peak numbers, defined as the "memory checkpoint." The need for these signals during the checkpoint could explain why many current influenza vaccines are poorly effective and elicit poor cellular immunity. We suggest that CD4 memory generation can be enhanced by re-vaccinating at this time. Our best hope lies in a universal vaccine that will not need to be formulated yearly against seasonal antigenically novel influenza strains and will also be protective against a pandemic strain. We suggest a vaccine approach that elicits a powerful T cell response, by initially inducing high levels of APC activation and later providing antigen at the memory checkpoint, may take us a step closer to such a universal influenza vaccine.

Keywords: influenza, vaccination, memory checkpoint, late-antigen, CD4 T cells, cell-mediated immunity

\section{INTRODUCTION}

Efforts to develop a vaccine for influenza date back to 1936 when the first live attenuated virus vaccine was produced in chicken eggs (1). Eighty years later, an effective influenza vaccine remains elusive, with the CDC reporting an overall vaccine efficacy of only $23 \%$ in the 2014-2015 influenza season (2). While influenza pandemics occur rarely, the H1N1 pandemic in 2009 also reminded us that they remain a major threat $(3,4)$. In this review, we discuss how CD4 T cells combat influenza viruses, with a focus on $\mathrm{CD} 4$ memory generation. We suggest strategies for improved influenza vaccines based on our new understanding of the mechanisms by which CD4 memory and functionally specialized effectors are generated. 


\section{INFLUENZA VIRUSES AND THE IMMUNE SYSTEM - A CONSTANTLY EVOLVING CHALLENGE}

Influenza A (IAV) and influenza B viruses infect humans causing widespread, sometimes fatal, disease. Both viruses contain eight gene segments, which encode surface proteins involved in viral attachment, entry and release from the cell, and internal proteins that predominantly play a role in viral replication (5-7). The two coat proteins, hemagglutinin (HA) and neuraminidase (NA), on the outer envelope are used to subtype the virus.

Each year new variants of influenza viral strains become dominant because of the high rate of mutations of the RNA virus. "Antigenic drift," one of the strongest drivers of viral evolution, results from the error-prone replication process (6) in conjunction with immune clearance based primarily on recognition of HA and NA by neutralizing antibody (Ab) (6). By virtue of their surface expression and abundance, the HA and NA contain the dominant epitopes recognized by $\mathrm{Ab}$ and to a lesser degree by responding $\mathrm{T}$ cells (8). Viruses having mutations in key epitopes can evade the immune system resulting in yearly drift within strains (9-12). "Antigenic shifts" that cause pandemics arise when re-assortment of influenza virus gene segments, often from different host species, occur (13).

Current vaccines rely largely on the induction of influenzaspecific Ab (14). New influenza vaccines are needed yearly to target the mutated epitopes in circulating strains predicted to dominate the upcoming flu season, but the predictions can be wrong leading to poor vaccine efficacy like that seen over the past two flu seasons (15-17). Antigenic mutations also make vaccine production logistically difficult as viruses can also mutate during the processes used in vaccine production (18).

Studies of viral evolution over the years indicate that while only $2.7 \%$ of epitopes recognized by $\mathrm{Ab}$ are conserved, $15 \%$ of T cell epitopes remain unchanged (8). This higher conservation of $T$ cell epitopes correlates with the ability of $T$ cells to target internal viral proteins involved in replication, which are far less tolerant to selection pressure compared to the external coat proteins (19-21). For example, the HA and NA of the pandemic H1N1 strain have acquired mutations at a rate six to eight times faster than the internal NP protein, in terms of amino acids substitutions per site per year (22). Ultimately an ideal vaccine that also combats viral escape would be one that elicits a broad immune response against the whole virus - a response which includes CD4 and $\mathrm{CD} 8$ memory responses in addition to $\mathrm{Ab}$ responses.

Thus, we suggest that a better understanding of the generation of $\mathrm{T}$ cell memory could lead to the development of vaccine strategies that induce more memory $\mathrm{T}$ cells, which are better able to recognize yearly influenza strain variants and new pandemic strains, providing longer-lived protection.

\section{CD4 EFFECTOR RESPONSES AGAINST INFLUENZA}

The first line of immune defense upon infection is comprised of PRR (pattern recognition receptor) pathways induced by the virus in infected epithelium, DCs, alveolar macrophages, and other myeloid cells triggered by viral PAMPs (pathogen associated molecular patterns) that act to induce innate defenses upon infection (23). PRR-activated cells also produce the inflammatory cytokines that promote the APC activation required for optimal $\mathrm{T}$ cell priming and costimulate adaptive $\mathrm{T}$ and $\mathrm{B}$ cell responses (23).

Activated APC migrate to the secondary lymphoid organs as early as 2 days post infection to present antigen to naive $\mathrm{T}$ cells (24). Effective CD4 T cell activation requires three distinct signals: antigen recognition by TCR, costimulation of CD28 on the $\mathrm{T}$ cell by CD80/86 on APC, and APC-produced costimulatory cytokine(s). Together, these signals drive CD4 T cell activation, with the cytokine milieu being a major factor in determining polarization into $\mathrm{Th} 1, \mathrm{Th} 2$, or Th17 subsets $(25,26)$. Regulatory $\mathrm{T}\left(\mathrm{T}_{\mathrm{REG}}\right)$ cells are also induced during influenza infections (27-29).

Influenza A virus infection predominantly induces a Th1 response, with most $\mathrm{CD} 4$ effectors producing IFN $\gamma$ though the importance of IFN $\gamma$ in combating the flu has been debated (26). Th17 effectors that contribute to protection are produced during IAV infections (30), but they also contribute to immunopathology (31). The polarization of T helper subsets during IAV infections has been previously reviewed $(25,26)$ and will not be discussed further.

While one of the classical functions of CD4 T cells is to help CD8 T cell effector generation, such help is not important for an effective primary immune response to influenza (32). However, recent studies have shown an important role for $\mathrm{CD} 4$ help during CD8 priming in the formation of $\mathrm{CD} 8$ resident memory $\mathrm{T}\left(\mathrm{T}_{\mathrm{RM}}\right)$ cells in lung airways during influenza infection $(32,33)$. CD4 $\mathrm{T}$ cells also regulate CD8 effector responses during IAV infections by modulating IL- 10 production by CD $8 \mathrm{~T}$ cells (34) and by counteracting $\mathrm{T}_{\mathrm{REG}}$ suppression (35).

Two other functionally specialized CD4 effector subsets that appear later in the response are $\mathrm{T}$ follicular helper cells $\left(\mathrm{T}_{\mathrm{FH}}\right)$ and cytotoxic CD4 $\mathrm{T}$ cells (ThCTL). $\mathrm{T}_{\mathrm{FH}}$ promote $\mathrm{T}$-dependent $\mathrm{B}$ cell responses. $\mathrm{T}_{\mathrm{FH}}$ lineage fate is determined in part by expression of transcription factor Bcl6 followed by upregulation of CXCR5, which causes the helper $\mathrm{T}$ cell to migrate to the germinal center (36). $T_{\mathrm{FH}}$ drive $\mathrm{B}$ cell survival, proliferation, class switching, plasma cell differentiation, and somatic hypermutation that take place in germinal centers (37). Germinal center T-dependent $\mathrm{B}$ cell responses are also required for generating memory $\mathrm{B}$ cells and later long-lived plasma cell (LLPC)-derived Ab responses that confer protection against reinfection $(25,38,39)$. Direct evidence of the importance of the $\mathrm{T}_{\mathrm{FH}}$ subset in mounting an immune response against IAV comes from human influenza vaccine studies that correlate efficacy of protective $\mathrm{Ab}$ responses generated to the number of $\mathrm{T}_{\mathrm{FH}}$ cells detected in the blood (40-43).

Cytotoxic CD4 $\mathrm{T}$ cells are effector CD4 T cells that mediate perforin-dependent, MHC Class-II specific cytotoxic activity. They are tissue-restricted, and in mouse models of IAV, infections are seen only in the lung (44-46). Although MHC-II expression is restricted to APC under steady state conditions, MHC-II is upregulated on infected epithelial cells in the lung during IAV infection (45). ThCTL could therefore mediate clearance of infected epithelial cells and contribute to clearance of the virus. Their contribution to the immune response against IAV is, however, 
often masked by other multiple redundant effector mechanisms $(44,47)$. The regulation and differentiation of this subset remain to be fully elucidated, though recent studies in a mouse model of IAV suggest a role of Blimp-1 and type I interferon pathways in ThCTL formation (48). Thus, ThCTL represent a uniquely regulated $\mathrm{CD} 4 \mathrm{~T}$ cell subset to target in vaccine approaches.

\section{AGING IMPAIRS CD4 T CELL HELPER RESPONSES AGAINST INFLUENZA}

Influenza infections cause extensive morbidity and mortality among the aged and current vaccines fail to provide widespread protection in this at-risk subset of the population $(49,50)$. B cell Ab responses (49), especially IgG responses (51) and induction of LLPC key to protection against re-infection, are impaired in aged mouse models. We have found that, in mice, reduced naive CD4 T cell responses can be enhanced by activation of the APC by TLR agonists, and this dramatic effect is dependent on IL-6 $(52,53)$. Young naive cell responses are also enhanced by the same mechanism (50), as are responses of aged human CD8 T cells $(49,54)$. Thus, we suggest that strategies, which couple antigen with agents that specifically activate relevant APC to produce IL-6 may improve vaccines for the aged.

\section{CD4 T CELL MEMORY}

Memory CD4 and CD8 T cells can provide strong protection in the absence of neutralizing $\mathrm{Ab}$ following heterosubtypic infection in mouse models of IAV infection $(45,47,55)$. Memory T cells were originally thought to be stem-like, retaining pluripotent potential (56), but new developments have demonstrated that memory $\mathrm{T}$ cells generated following infection are mostly composed of multiple highly differentiated subsets, which mediate the enhanced protective ability of memory over naive $\mathrm{T}$ cells.

Memory CD4 T cells generated by live infection retain some of the differentiation-associated changes attained during the effector phase of the response. CXCR5 expressing memory CD4 T cells are capable of enhanced B cell help during re-challenge, although they are also capable of differentiation into many different cytokine-secreting subsets during the secondary response $(55,57,58)$. Th1-like memory cells were identified in one report by a lack of CXCR5 expression and in another by increased Ly6C expression. Using either method, isolated memory cells largely became IFN $\gamma$-producing Th 1 cells during the secondary response, demonstrating far less plasticity than the CXCR $5^{+}$memory T cells $(57,58)$. This retention of functional imprinting that occurs in the effector phase may account for some of the enhanced function during the secondary response (59).

Lung CD4 $\mathrm{T}_{\mathrm{RM}}$ cells have recently been characterized following influenza infection. This subset, which is thought to be present at the frontline of infection in tissues, is critical for protection against a lethal dose of IAV (60). While studies have demonstrated that antigen recognition in the lung along with TGF $\beta$ signals are required for the formation of CD8 $\mathrm{T}_{\mathrm{RM}}$ during influenza infection, it is unclear if CD4 $\mathrm{T}_{\mathrm{RM}}$ cells have similar requirements (61). Both lung $\mathrm{T}_{\mathrm{RM}} \mathrm{CD} 4$ and $\mathrm{CD} 8 \mathrm{~T}$ cells express
CD69, but only CD8 $\mathrm{T}_{\mathrm{RM}}$ cells express CD103 (62), suggesting the two populations may occupy different niches within the lung or that they may be differently regulated.

Memory CD4 $\mathrm{T}$ cells provide protection via multiple synergizing mechanisms including both IFN $\gamma$-dependent and -independent mechanisms, cytotoxic mechanisms, help for B cells and rapid induction of innate inflammatory responses $(25,26,47)$. Additionally, the presence of cross-reactive memory CD4 T cells has been correlated with less severe disease following heterosubtypic infection in humans (63). Therefore, the ability to induce CD4 memory responses is central to the development of vaccines that are more potent, broader in specificity and would also benefit from the synergy of multiple functional pathways to eliminate the virus.

\section{LATE-ANTIGEN SHAPES EFFICIENT T CELL EFFECTOR AND MEMORY RESPONSES}

Viral clearance occurs by days 10-13 of IAV infection, but antigen presentation can occur for up to 3 weeks (64). While early priming events are sufficient for some effector and memory $\mathrm{T}$ cell differentiation (65-67), recent studies have identified a role for signals received at the effector stage in shaping ongoing CD4 $\mathrm{T}$ cell responses. CD28 signals, after priming, have been shown to be required for full Th1 and $\mathrm{T}_{\mathrm{FH}}$ differentiation in IAV (68). A second round of antigen recognition is also required for full $\mathrm{T}_{\mathrm{FH}}$ differentiation (69-71).

Multiple studies have suggested that CD4 T cells require longer periods of antigen stimulation during antigen priming compared to CD8 T cells for effector function and proliferation (72-75). Some studies have also found that CD8 effector T cells require antigen stimulation after initial priming, out to 8 days after IAV infection for continued proliferation and survival $(76,77)$. One study identified a defined window from days 5 to 8 following administration of initial antigen, when antigen with adjuvant prevents apoptosis of effector CD8 T cells (78). Therefore, while the requirements during priming may be different for CD4 and CD8 T cells, it appears their response to antigen at the effector stage may be similar.

In addition to shaping effector responses, recent studies have highlighted the role of late signals in promoting the formation of functional, protective memory $\mathrm{T}$ cell populations. Late-antigen recognition, 5-8 days after infection, promotes the formation of protective memory CD8 T cells $(79,80)$. In the IAV infection model, we found that costimulation and IL-2 signaling during 5-7 days after initial priming are required for almost all CD4 memory cells to form (81). We have defined this time, 5-7 days after primary antigen encounter, as the "memory checkpoint." Our study also showed that cognate MHC-II interactions and CD27-CD70 interactions are required at this checkpoint for efficient transition of CD4 effectors to memory (81).

It is well established that during chronic infections, antigen persistence drives $\mathrm{T}$ cell exhaustion (82). Some studies show that TCR stimulation 7 days after the response results in apoptosis of CD8 T cells (78). Others have found that after 10 days of antigen 
stimulation, CD4 T cells begin to express an exhausted phenotype (83). Thus, the memory checkpoint appears to be a tightly regulated time window during which antigen presentation has a substantial impact on the effector and memory $\mathrm{T}$ cells generated, beyond which antigen may drive exhaustion.

Some have found that late-antigen presentation to CD8 T cells occurs primarily in the lung $(61,77,84)$, while others believe it also occurs in the lung-draining lymph nodes (85). It is yet unclear where antigen presentation during the effector phase occurs for CD4 T cells. It is conceivable that antigen recognition during the CD4 effector phase also occurs in the SLO since $\mathrm{T}_{\mathrm{FH}}$ must recognize late-antigen to provide help (36). We speculate that antigen recognition at the effector phase in the SLO provides signals that generate a circulating, central memory population, while antigen recognition in the lung during the effector phase may lead to $\mathrm{T}_{\mathrm{RM}}$ formation.

Thus, although small numbers of less differentiated memory cells may be formed following initial priming alone, additional cognate interactions are required at the "memory checkpoint" during the effector phase for the formation of large, functional CD4 memory populations (81). Given the many ways distinct CD4 subsets orchestrate the immune response, their continued dependence on antigen and costimulation for effector function and further differentiation may dictate the fate of distinct CD4 subsets and thus tailor the response.

\section{PERSPECTIVE ON TRANSLATING RECENT ADVANCES INTO IMPROVED INFLUENZA VACCINES}

Given the challenges posed by influenza viruses and the recent advances in understanding CD4 $\mathrm{T}$ cell immune responses and memory summarized above, we suggest new strategies at two different levels that may enable an improved vaccine (Figure 1).

There are currently three classes of seasonal influenza vaccines in use: inactivated influenza vaccines consisting of both split-virion and subunit vaccines (IIV), live attenuated influenza vaccines (LAIV), and recombinant $H A$ vaccines $(14,86)$. The multivalent vaccines contain components of both type $\mathrm{A}$ and type $B$ viruses predicted to circulate in the upcoming influenza season. Both inactivated and new recombinant vaccines (commercially known as FluBlok ${ }^{\circledR}$ consist of HA with or without NA purified from viruses cultured in eggs or in cell culture and inactivated or made as a recombinant protein using baculovirus expression systems in insect cells, respectively (87). Live attenuated vaccines (commercially known as FluMist ${ }^{\circledR}$ ) are composed of cold-adapted viruses that do not survive at temperatures above $37^{\circ} \mathrm{C}$ and thus only infect the upper respiratory tract in humans and cause very mild infections sufficient to elicit modest immunity (14).

Both LAIV and IIV have been demonstrated to be equally effective in adults, while in children LAIV has demonstrated superior efficacy in various studies (86). This increased efficacy in children has been attributed to the wider range and longer-lived immune responses that LAIV elicits. While IIV primarily elicits

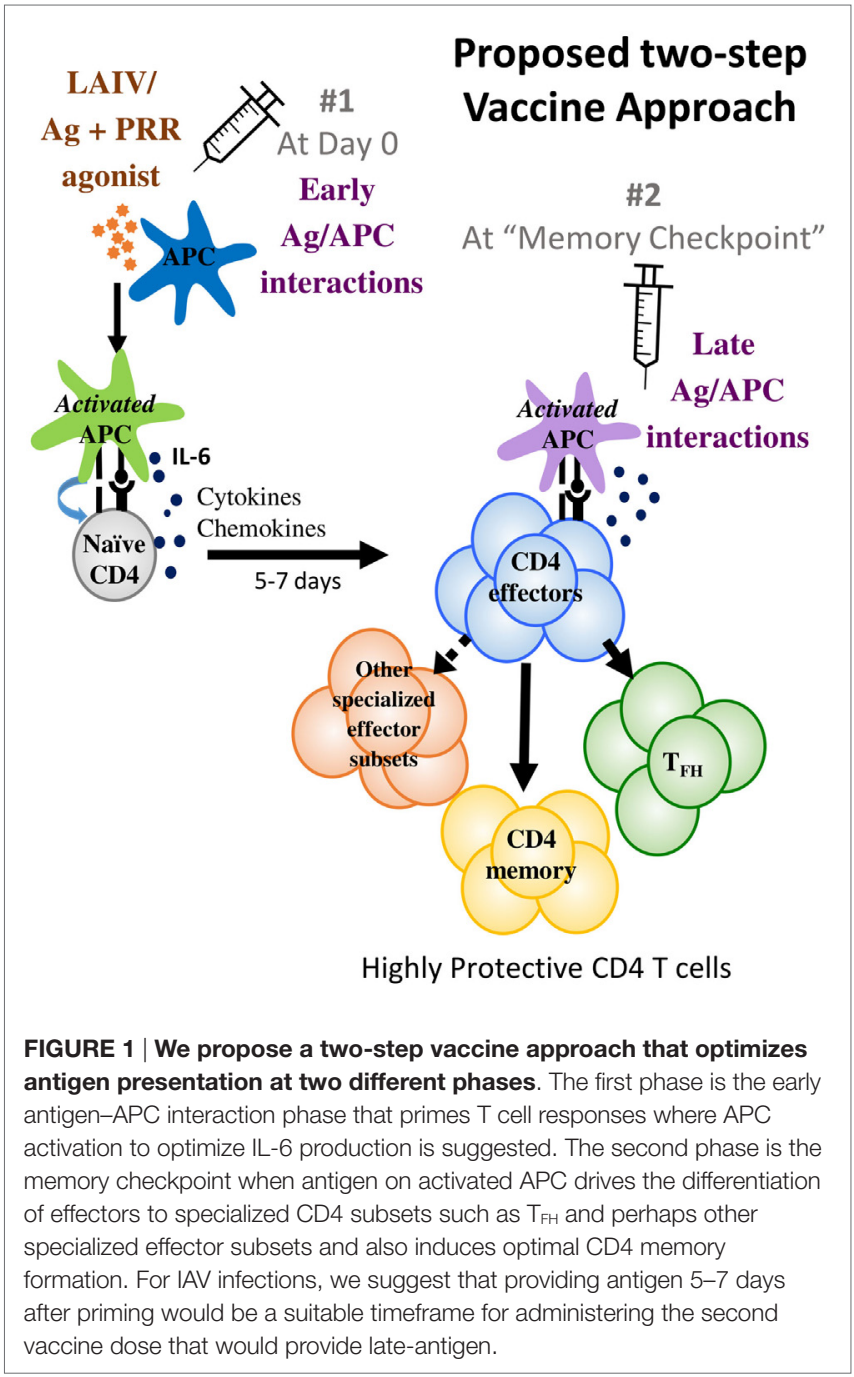

IgG serum Ab responses against HA, LAIV has been shown to elicit a wider range of $\mathrm{Ab}$ responses including $\operatorname{IgG}$ and $\mathrm{IgA}$ against both HA and NA viral proteins. LAIV responses also promote CD4 and CD8 $\mathrm{T}$ cell responses against internal viral proteins and if these become memory $\mathrm{T}$ cells, they could be cross-protective against antigenically novel pandemic as well as seasonal epidemic influenza strains $(8,88)$.

Replicating live virus is likely to be the best at inducing APC activation through PRR pathways, a critical step in an effective helper T cell response. Production of IL- 6 by the activated APC would also contribute to enhanced priming of young and aged responses, as discussed. This would explain the enhanced efficacy of LAIV compared to IIV. Partially purified IIV may induce minor activation through the remaining RNA and DNA present, while recombinant or highly purified subunit proteins are likely to be devoid of most PRR-inducing ability. Adjuvants could be used to enhance PRR responses in APCs, though further research will be required to achieve optimal activation without causing widespread inflammation (89). DC vaccines targeting antigen to PRR-activated APCs could also potentially be used to achieve similar strong initial $\mathrm{T}$ cell responses (90). 
However, even with LAIV, it is likely the level of antigen presentation decreases with time since replication does not occur in the lung and is not likely to be high during the effector phase of the T cell response $(91,92)$, through the memory checkpoint, when such presentation is important for efficient $\mathrm{T}$ cell memory induction. Data also suggest that antigen presentation specifically in the lung is important to drive CD8 $\mathrm{T}_{\mathrm{RM}}$ responses to IAV (61). Thus, we suggest that additional antigen that can be presented by activated APC could be administered at the effector checkpoint through the intranasal route, a hypothesis we are currently testing in the mouse model. A vaccine strategy including an early "boost" has indeed generated superior CD8 memory in mice thus lending support to the concept (93). We suggest that additional antigen priming at the memory checkpoint would both enhance $\mathrm{T}$ cell memory and potentially increase $\mathrm{T}_{\mathrm{FH}}$ responses, which also require late-antigen encounter and are correlated directly with successful $\mathrm{Ab}$ titers and viral clearance.

A more robust "T cell" vaccine incorporating these strategies should promote larger and longer lived $\mathrm{Ab}$ responses like those achieved by viral infection and generate more multi-functional memory $\mathrm{T}$ cells that are cross-reactive to antigenically novel strains. This might give us a recipe for a more "universal" influenza vaccine that would not need to be reformulated every year

\section{REFERENCES}

1. Hannoun C. The evolving history of influenza viruses and influenza vaccines. Expert Rev Vaccines (2013) 12(9):1085-94. doi:10.1586/14760584. 2013.824709

2. CDC. Seasonal Influenza Vaccine Effectiveness, 2005-2015. (2015). Available from: http://www.cdc.gov/flu/professionals/vaccination/effectiveness-studies. htm

3. Broadbent AJ, Subbarao K. Influenza virus vaccines: lessons from the 2009 H1N1 pandemic. Curr Opin Virol (2011) 1(4):254-62. doi:10.1016/j. coviro.2011.08.002

4. Pada S, Tambyah PA. Overview/reflections on the $2009 \mathrm{H} 1 \mathrm{~N} 1$ pandemic. Microbes Infect (2011) 13(5):470-8. doi:10.1016/j.micinf.2011.01.009

5. Eisfeld AJ, Neumann G, Kawaoka Y. At the centre: influenza A virus ribonucleoproteins. Nat Rev Microbiol (2015) 13(1):28-41. doi:10.1038/nrmicro3367

6. Medina RA, Garcia-Sastre A. Influenza A viruses: new research developments. Nat Rev Microbiol (2011) 9(8):590-603. doi:10.1038/nrmicro2613

7. Vasin AV, Temkina OA, Egorov VV, Klotchenko SA, Plotnikova MA, Kiselev OI. Molecular mechanisms enhancing the proteome of influenza A viruses: an overview of recently discovered proteins. Virus Res (2014) 185:53-63. doi:10.1016/j.virusres.2014.03.015

8. Bui HH, Peters B, Assarsson E, Mbawuike I, Sette A. Ab and T cell epitopes of influenza A virus, knowledge and opportunities. Proc Natl Acad Sci U S A (2007) 104(1):246-51. doi:10.1073/pnas.0609330104

9. Huang KY, Rijal P, Schimanski L, Powell TJ, Lin TY, McCauley JW, et al. Focused antibody response to influenza linked to antigenic drift. J Clin Invest (2015) 125(7):2631-45. doi:10.1172/JCI81104

10. Hensley SE, Das SR, Bailey AL, Schmidt LM, Hickman HD, Jayaraman A, et al. Hemagglutinin receptor binding avidity drives influenza A virus antigenic drift. Science (2009) 326(5953):734-6. doi:10.1126/science.1178258

11. Gerber P, Loosli CG, Hambre D. Antigenic variants of influenza A virus, PR8 strain. I. Their development during serial passage in the lungs of partially immune mice. J Exp Med (1955) 101(6):627-38. doi:10.1084/jem.101.6.627

12. Lambkin R, McLain L, Jones SE, Aldridge SL, Dimmock NJ. Neutralization escape mutants of type A influenza virus are readily selected by antisera from mice immunized with whole virus: a possible mechanism for antigenic drift. J Gen Virol (1994) 75(Pt 12):3493-502. doi:10.1099/0022-1317-75-12-3493 and would provide some protection against potentially pandemic strains.

\section{AUTHOR CONTRIBUTIONS}

PD organized the different sections of the manuscript, coordinated other author contributions, put together the sections in the manuscript, sent out for review to all authors, and finalized the manuscript for submission. $\mathrm{BB}$ wrote the section on $\mathrm{T}$ cell memory and on Late-antigen, helped organize different sections of the manuscript, and helped finalize the manuscript for submission. AV, KM, and TS helped organize different sections of the manuscript, contributed their insights on all sections in the manuscript, and helped finalize the manuscript for submission. SS wrote the section on aging responses, organized different sections of the manuscript, and finalized the manuscript for submission.

\section{FUNDING}

The authors have been supported by grants from NIH to SS: R01AI118820, P01AI046530, R01AI076534, and Project 2 of U19AI109858 (to Welsh) and from AHA to KM 14SDG18600020.

13. De Jong JC, Rimmelzwaan GF, Fouchier RA, Osterhaus AD. Influenza virus: a master of metamorphosis. J Infect (2000) 40(3):218-28. doi:10.1053/ jinf.2000.0652

14. Houser K, Subbarao K. Influenza vaccines: challenges and solutions. Cell Host Microbe (2015) 17(3):295-300. doi:10.1016/j.chom.2015.02.012

15. Chambers BS, Parkhouse K, Ross TM, Alby K, Hensley SE. Identification of hemagglutinin residues responsible for $\mathrm{H} 3 \mathrm{~N} 2$ antigenic drift during the 2014-2015 influenza season. Cell Rep (2015) 12(1):1-6. doi:10.1016/j. celrep.2015.06.005

16. Linderman SL, Chambers BS, Zost SJ, Parkhouse K, Li Y, Herrmann C, et al. Potential antigenic explanation for atypical H1N1 infections among middle-aged adults during the 2013-2014 influenza season. Proc Natl Acad Sci U S A (2014) 111(44):15798-803. doi:10.1073/pnas.1409171111

17. Xie H, Wan XF, Ye Z, Plant EP, Zhao Y, Xu Y, et al. H3N2 mismatch of 201415 Northern Hemisphere influenza vaccines and head-to-head comparison between human and ferret antisera derived antigenic maps. Sci Rep (2015) 5:15279. doi:10.1038/srep15279

18. Skowronski DM, Janjua NZ, De Serres G, Sabaiduc S, Eshaghi A, Dickinson JA, et al. Low 2012-13 influenza vaccine effectiveness associated with mutation in the egg-adapted $\mathrm{H} 3 \mathrm{~N} 2$ vaccine strain not antigenic drift in circulating viruses. PLoS One (2014) 9(3):e92153. doi:10.1371/journal.pone.0092153

19. Westgeest KB, Russell CA, Lin X, Spronken MI, Bestebroer TM, Bahl J, et al. Genomewide analysis of reassortment and evolution of human influenza A(H3N2) viruses circulating between 1968 and 2011. J Virol (2014) 88(5):2844-57. doi:10.1128/JVI.02163-13

20. Heaton NS, Sachs D, Chen CJ, Hai R, Palese P. Genome-wide mutagenesis of influenza virus reveals unique plasticity of the hemagglutinin and NS1 proteins. Proc Natl Acad Sci U S A (2013) 110(50):20248-53. doi:10.1073/ pnas. 1320524110

21. Bhatt S, Holmes EC, Pybus OG. The genomic rate of molecular adaptation of the human influenza A virus. Mol Biol Evol (2011) 28(9):2443-51. doi:10.1093/ molbev/msr044

22. Klein EY, Serohijos AW, Choi JM, Shakhnovich EI, Pekosz A. Influenza A H1N1 pandemic strain evolution - divergence and the potential for antigenic drift variants. PLoS One (2014) 9(4):e93632. doi:10.1371/journal.pone.0093632

23. Iwasaki A, Pillai PS. Innate immunity to influenza virus infection. Nat Rev Immunol (2014) 14(5):315-28. doi:10.1038/nri3665 
24. Braciale TJ, Sun J, Kim TS. Regulating the adaptive immune response to respiratory virus infection. Nat Rev Immunol (2012) 12(4):295-305. doi:10.1038/nri3166

25. Swain SL, McKinstry KK, Strutt TM. Expanding roles for CD4(+) T cells in immunity to viruses. Nat Rev Immunol (2012) 12(2):136-48. doi:10.1038/ nri3152

26. Strutt TM, McKinstry KK, Marshall NB, Vong AM, Dutton RW, Swain SL. Multipronged $\mathrm{CD} 4(+)$ T-cell effector and memory responses cooperate to provide potent immunity against respiratory virus. Immunol Rev (2013) 255(1):149-64. doi:10.1111/imr.12088

27. Betts RJ, Prabhu N, Ho AW, Lew FC, Hutchinson PE, Rotzschke O, et al. Influenza A virus infection results in a robust, antigen-responsive, and widely disseminated Foxp3+ regulatory T cell response. J Virol (2012) 86(5):2817-25. doi:10.1128/JVI.05685-11

28. Bedoya F, Cheng GS, Leibow A, Zakhary N, Weissler K, Garcia V, et al. Viral antigen induces differentiation of Foxp3+ natural regulatory $\mathrm{T}$ cells in influenza virus-infected mice. J Immunol (2013) 190(12):6115-25. doi:10.4049/ jimmunol.1203302

29. Brincks EL, Roberts AD, Cookenham T, Sell S, Kohlmeier JE, Blackman MA, et al. Antigen-specific memory regulatory CD4+Foxp3+ T cells control memory responses to influenza virus infection. J Immunol (2013) 190(7):3438-46. doi:10.4049/jimmunol.1203140

30. McKinstry KK, Strutt TM, Buck A, Curtis JD, Dibble JP, Huston G, et al. IL-10 deficiency unleashes an influenza-specific Th17 response and enhances survival against high-dose challenge. J Immunol (2009) 182(12):7353-63. doi:10.4049/jimmunol.0900657

31. Crowe CR, Chen K, Pociask DA, Alcorn JF, Krivich C, Enelow RI, et al. Critical role of IL-17RA in immunopathology of influenza infection. J Immunol (2009) 183(8):5301-10. doi:10.4049/jimmunol.0900995

32. Belz GT, Wodarz D, Diaz G, Nowak MA, Doherty PC. Compromised influenza virus-specific CD8(+)-T-cell memory in CD4(+)-T-cell-deficient mice. J Virol (2002) 76(23):12388-93. doi:10.1128/JVI.76.23.12388-12393.2002

33. Laidlaw BJ, Zhang N, Marshall HD, Staron MM, Guan T, Hu Y, et al. CD4+ $\mathrm{T}$ cell help guides formation of CD103+ lung-resident memory CD8+ T cells during influenza viral infection. Immunity (2014) 41(4):633-45. doi:10.1016/j. immuni.2014.09.007

34. Sun J, Dodd H, Moser EK, Sharma R, Braciale TJ. CD4+ T cell help and innate-derived IL-27 induce Blimp-1-dependent IL-10 production by antiviral CTLs. Nat Immunol (2011) 12(4):327-34. doi:10.1038/ni.1996

35. Ballesteros-Tato A, Leon B, Lund FE, Randall TD. CD4+ T helper cells use CD154-CD40 interactions to counteract $\mathrm{T}$ reg cell-mediated suppression of CD8+ T cell responses to influenza. J Exp Med (2013) 210(8):1591-601. doi:10.1084/jem.20130097

36. Crotty $\mathrm{S}$. T follicular helper cell differentiation, function, and roles in disease. Immunity (2014) 41(4):529-42. doi:10.1016/j.immuni.2014.10.004

37. Crotty S. A brief history of T cell help to B cells. Nat Rev Immunol (2015) 15(3):185-9. doi:10.1038/nri3803

38. Kamperschroer C, Dibble JP, Meents DL, Schwartzberg PL, Swain SL. SAP is required for Th cell function and for immunity to influenza. J Immunol (2006) 177(8):5317-27. doi:10.4049/jimmunol.177.8.5317

39. Waffarn EE, Baumgarth N. Protective B cell responses to flu - no fluke! J Immunol (2011) 186(7):3823-9. doi:10.4049/jimmunol.1002090

40. van der Most RG, Roman FP, Innis B, Hanon E, Vaughn DW, Gillard P, et al. Seeking help: B cells adapting to flu variability. Sci Transl Med (2014) 6(246):246s8. doi:10.1126/scitranslmed.3008409

41. Spensieri F, Borgogni E, Zedda L, Bardelli M, Buricchi F, Volpini G, et al. Human circulating influenza-CD4+ ICOS1+IL-21+ T cells expand after vaccination, exert helper function, and predict antibody responses. Proc Natl Acad Sci U S A (2013) 110(35):14330-5. doi:10.1073/pnas.1311998110

42. Herati RS, Reuter MA, Dolfi DV, Mansfield KD, Aung H, Badwan OZ, et al. Circulating CXCR5+PD-1+ response predicts influenza vaccine antibody responses in young adults but not elderly adults. J Immunol (2014) 193(7):3528-37. doi:10.4049/jimmunol.1302503

43. Bentebibel SE, Lopez S, Obermoser G, Schmitt N, Mueller C, Harrod C, et al. Induction of ICOS+CXCR3+CXCR5+ TH cells correlates with antibody responses to influenza vaccination. Sci Transl Med (2013) 5(176):176ra32. doi:10.1126/scitranslmed.3005191
44. Brown DM, Dilzer AM, Meents DL, Swain SL. CD4 T cell-mediated protection from lethal influenza: perforin and antibody-mediated mechanisms give a one-two punch. J Immunol (2006) 177(5):2888-98. doi:10.4049/ jimmunol.177.5.2888

45. Brown DM, Lee S, Garcia-Hernandez Mde L, Swain SL. Multifunctional CD4 cells expressing gamma interferon and perforin mediate protection against lethal influenza virus infection. J Virol (2012) 86(12):6792-803. doi:10.1128/ JVI.07172-11

46. Marshall NB, Swain SL. Cytotoxic CD4 T cells in antiviral immunity. J Biomed Biotechnol (2011) 2011:954602. doi:10.1155/2011/954602

47. McKinstry KK, Strutt TM, Kuang Y, Brown DM, Sell S, Dutton RW, et al. Memory CD4+ T cells protect against influenza through multiple synergizing mechanisms. J Clin Invest (2012) 122(8):2847-56. doi:10.1172/JCI63689

48. Hua L, Yao S, Pham D, Jiang L, Wright J, Sawant D, et al. Cytokine-dependent induction of $\mathrm{CD} 4+\mathrm{T}$ cells with cytotoxic potential during influenza virus infection. J Virol (2013) 87(21):11884-93. doi:10.1128/JVI.01461-13

49. McElhaney JE, Kuchel GA, Zhou X, Swain SL, Haynes L. T-cell immunity to influenza in older adults: a pathophysiological framework for development of more effective vaccines. Front Immunol (2016) 7:41. doi:10.3389/ fimmu.2016.00041

50. McElhaney JE. Influenza vaccine responses in older adults. Ageing Res Rev (2011) 10(3):379-88. doi:10.1016/j.arr.2010.10.008

51. Eaton SM, Burns EM, Kusser K, Randall TD, Haynes L. Age-related defects in $\mathrm{CD} 4 \mathrm{~T}$ cell cognate helper function lead to reductions in humoral responses. J Exp Med (2004) 200(12):1613-22. doi:10.1084/jem.20041395

52. Jones SC, Brahmakshatriya V, Huston G, Dibble J, Swain SL. TLR-activated dendritic cells enhance the response of aged naive CD4 T cells via an IL-6dependent mechanism. JImmunol (2010) 185(11):6783-94. doi:10.4049/ jimmunol.0901296

53. Zhang W, Brahmakshatriya V, Swain SL. CD4 T cell defects in the aged: causes, consequences and strategies to circumvent. Exp Gerontol (2014) 54:67-70. doi:10.1016/j.exger.2014.01.002

54. Behzad H, Huckriede AL, Haynes L, Gentleman B, Coyle K, Wilschut JC, et al. GLA-SE, a synthetic toll-like receptor 4 agonist, enhances T-cell responses to influenza vaccine in older adults. J Infect Dis (2012) 205(3):466-73. doi:10.1093/infdis/jir769

55. MacLeod MK, David A, McKee AS, Crawford F, Kappler JW, Marrack P. Memory CD4 T cells that express CXCR5 provide accelerated help to B cells. J Immunol (2011) 186(5):2889-96. doi:10.4049/jimmunol.1002955

56. Kaech SM, Wherry EJ, Ahmed R. Effector and memory T-cell differentiation: implications for vaccine development. Nat Rev Immunol (2002) 2(4):251-62. doi: $10.1038 /$ nri778

57. Hale JS, Youngblood B, Latner DR, Mohammed AU, Ye L, Akondy RS, et al. Distinct memory CD4+ T cells with commitment to $\mathrm{T}$ follicular helper- and $\mathrm{T}$ helper 1-cell lineages are generated after acute viral infection. Immunity (2013) 38(4):805-17. doi:10.1016/j.immuni.2013.02.020

58. Pepper M, Pagan AJ, Igyarto BZ, Taylor JJ, Jenkins MK. Opposing signals from the Bcl6 transcription factor and the interleukin-2 receptor generate T helper 1 central and effector memory cells. Immunity (2011) 35(4):583-95. doi:10.1016/j.immuni.2011.09.009

59. Strutt TM, McKinstry KK, Kuang Y, Bradley LM, Swain SL. Memory CD4+ T-cell-mediated protection depends on secondary effectors that are distinct from and superior to primary effectors. Proc Natl Acad Sci U S A (2012) 109(38):E2551-60. doi:10.1073/pnas.1205894109

60. Teijaro JR, Turner D, Pham Q, Wherry EJ, Lefrancois L, Farber DL. Cutting edge: tissue-retentive lung memory CD4 T cells mediate optimal protection to respiratory virus infection. J Immunol (2011) 187(11):5510-4. doi:10.4049/ jimmunol.1102243

61. Wakim LM, Smith J, Caminschi I, Lahoud MH, Villadangos JA. Antibodytargeted vaccination to lung dendritic cells generates tissue-resident memory CD8 $\mathrm{T}$ cells that are highly protective against influenza virus infection. Mucosal Immunol (2015) 8(5):1060-71. doi:10.1038/mi.2014.133

62. Turner DL, Bickham KL, Thome JJ, Kim CY, D'Ovidio F, Wherry EJ, et al. Lung niches for the generation and maintenance of tissue-resident memory $\mathrm{T}$ cells. Mucosal Immunol (2014) 7(3):501-10. doi:10.1038/mi.2013.67

63. Wilkinson TM, Li CK, Chui CS, Huang AK, Perkins M, Liebner JC, et al. Preexisting influenza-specific CD4+ T cells correlate with 
disease protection against influenza challenge in humans. Nat Med (2012) 18(2):274-80. doi:10.1038/nm.2612

64. Jelley-Gibbs DM, Brown DM, Dibble JP, Haynes L, Eaton SM, Swain SL. Unexpected prolonged presentation of influenza antigens promotes CD4 T cell memory generation. J Exp Med (2005) 202(5):697-706. doi:10.1084/ jem. 20050227

65. Corbin GA, Harty JT. Duration of infection and antigen display have minimal influence on the kinetics of the $\mathrm{CD} 4+\mathrm{T}$ cell response to Listeria monocytogenes infection. JImmunol (2004) 173(9):5679-87. doi:10.4049/ jimmunol.173.9.5679

66. Hu H, Huston G, Duso D, Lepak N, Roman E, Swain SL. CD4(+) T cell effectors can become memory cells with high efficiency and without further division. Nat Immunol (2001) 2(8):705-10. doi:10.1038/90643

67. Gett AV, Sallusto F, Lanzavecchia A, Geginat J. T cell fitness determined by signal strength. Nat Immunol (2003) 4(4):355-60. doi:10.1038/ni908

68. Linterman MA, Denton AE, Divekar DP, Zvetkova I, Kane L, Ferreira C, et al. CD28 expression is required after T cell priming for helper $\mathrm{T}$ cell responses and protective immunity to infection. Elife (2014) 3:e03180. doi:10.7554/ eLife. 03180

69. Choi YS, Kageyama R, Eto D, Escobar TC, Johnston RJ, Monticelli L, et al. ICOS receptor instructs $\mathrm{T}$ follicular helper cell versus effector cell differentiation via induction of the transcriptional repressor Bcl6. Immunity (2011) 34(6):932-46. doi:10.1016/j.immuni.2011.03.023

70. Goenka R, Barnett LG, Silver JS, O’Neill PJ, Hunter CA, Cancro MP, et al. Cutting edge: dendritic cell-restricted antigen presentation initiates the follicular helper $\mathrm{T}$ cell program but cannot complete ultimate effector differentiation. J Immunol (2011) 187(3):1091-5. doi:10.4049/jimmunol.1100853

71. Barnett LG, Simkins HM, Barnett BE, Korn LL, Johnson AL, Wherry EJ, et al. $\mathrm{B}$ cell antigen presentation in the initiation of follicular helper $\mathrm{T}$ cell and germinal center differentiation. J Immunol (2014) 192(8):3607-17. doi:10.4049/ jimmunol.1301284

72. Kaech SM, Ahmed R. Memory CD8+ T cell differentiation: initial antigen encounter triggers a developmental program in naive cells. Nat Immunol (2001) 2(5):415-22. doi:10.1038/87720

73. Obst R, van Santen HM, Mathis D, Benoist C. Antigen persistence is required throughout the expansion phase of a CD4(+) T cell response. J Exp Med (2005) 201(10):1555-65. doi:10.1084/jem.20042521

74. Rabenstein H, Behrendt AC, Ellwart JW, Naumann R, Horsch M, Beckers J, et al. Differential kinetics of antigen dependency of CD4+ and CD8+ T cells. J Immunol (2014) 192(8):3507-17. doi:10.4049/jimmunol.1302725

75. Blair DA, Turner DL, Bose TO, Pham QM, Bouchard KR, Williams KJ, et al. Duration of antigen availability influences the expansion and memory differentiation of T cells. J Immunol (2011) 187(5):2310-21. doi:10.4049/ jimmunol.1100363

76. Dolfi DV, Duttagupta PA, Boesteanu AC, Mueller YM, Oliai CH, Borowski $\mathrm{AB}$, et al. Dendritic cells and CD28 costimulation are required to sustain virus-specific $\mathrm{CD} 8+\mathrm{T}$ cell responses during the effector phase in vivo. J Immunol (2011) 186(8):4599-608. doi:10.4049/jimmunol.1001972

77. McGill J, Van Rooijen N, Legge KL. Protective influenza-specific CD8 T cell responses require interactions with dendritic cells in the lungs. J Exp Med (2008) 205(7):1635-46. doi:10.1084/jem.20080314

78. Garrod KR, Moreau HD, Garcia Z, Lemaitre F, Bouvier I, Albert ML, et al. Dissecting $\mathrm{T}$ cell contraction in vivo using a genetically encoded reporter of apoptosis. Cell Rep (2012) 2(5):1438-47. doi:10.1016/j.celrep.2012.10.015

79. Slutter B, Pewe LL, Kaech SM, Harty JT. Lung airway-surveilling CXCR3(hi) memory CD8(+) T cells are critical for protection against influenza A virus. Immunity (2013) 39(5):939-48. doi:10.1016/j.immuni.2013.09.013
80. Leon B, Ballesteros-Tato A, Randall TD, Lund FE. Prolonged antigen presentation by immune complex-binding dendritic cells programs the proliferative capacity of memory CD8 T cells. J Exp Med (2014) 211(8):1637-55. doi:10.1084/jem.20131692

81. McKinstry KK, Strutt TM, Bautista B, Zhang W, Kuang Y, Cooper AM, et al. Effector CD4 T-cell transition to memory requires late cognate interactions that induce autocrine IL-2. Nat Commun (2014) 5:5377. doi:10.1038/ ncomms6377

82. Wherry EJ. T cell exhaustion. Nat Immunol (2011) 12(6):492-9. doi:10.1038/ ni. 2035

83. Han S, Asoyan A, Rabenstein H, Nakano N, Obst R. Role of antigen persistence and dose for CD4+ T-cell exhaustion and recovery. Proc Natl Acad Sci U S A (2010) 107(47):20453-8. doi:10.1073/pnas.1008437107

84. McGill J, Van Rooijen N, Legge KL. IL-15 trans-presentation by pulmonary dendritic cells promotes effector CD8 $\mathrm{T}$ cell survival during influenza virus infection. J Exp Med (2010) 207(3):521-34. doi:10.1084/jem.20091711

85. Ballesteros-Tato A, Leon B, Lund FE, Randall TD. Temporal changes in dendritic cell subsets, cross-priming and costimulation via CD70 control CD8(+) T cell responses to influenza. Nat Immunol (2010) 11(3):216-24. doi:10.1038/ ni. 1838

86. Grohskopf LA, Olsen SJ, Sokolow LZ, Bresee JS, Cox NJ, Broder KR, et al. Prevention and control of seasonal influenza with vaccines: recommendations of the Advisory Committee on Immunization Practices (ACIP) - United States, 2014-15 influenza season. MMWR Morb Mortal Wkly Rep (2014) 63(32):691-7.

87. Milian E, Kamen AA. Current and emerging cell culture manufacturing technologies for influenza vaccines. Biomed Res Int (2015) 2015:504831 doi:10.1155/2015/504831

88. Sridhar S, Brokstad KA, Cox RJ. Influenza vaccination strategies: comparing inactivated and live attenuated influenza vaccines. Vaccines (Basel) (2015) 3(2):373-89. doi:10.3390/vaccines3020373

89. Moyer TJ, Zmolek AC, Irvine DJ. Beyond antigens and adjuvants: formulating future vaccines. J Clin Invest (2016) 126(3):799-808. doi:10.1172/JCI81083

90. Cohn L, Delamarre L. Dendritic cell-targeted vaccines. Front Immunol (2014) 5:255. doi:10.3389/fimmu.2014.00255

91. Block SL, Yogev R, Hayden FG, Ambrose CS, Zeng W, Walker RE. Shedding and immunogenicity of live attenuated influenza vaccine virus in subjects 5-49 years of age. Vaccine (2008) 26(38):4940-6. doi:10.1016/j. vaccine.2008.07.013

92. Mallory RM, Yi T, Ambrose CS. Shedding of Ann Arbor strain live attenuated influenza vaccine virus in children 6-59 months of age. Vaccine (2011) 29(26):4322-7. doi:10.1016/j.vaccine.2011.04.022

93. Slutter B, Pewe LL, Lauer P, Harty JT. Cutting edge: rapid boosting of cross-reactive memory $\mathrm{CD} 8 \mathrm{~T}$ cells broadens the protective capacity of the Flumist vaccine. JImmunol (2013) 190(8):3854-8. doi:10.4049/ jimmunol.1202790

Conflict of Interest Statement: The authors declare that the research was conducted in the absence of any commercial or financial relationships that could be construed as a potential conflict of interest.

Copyright $₫ 2016$ Devarajan, Bautista, Vong, McKinstry, Strutt and Swain. This is an open-access article distributed under the terms of the Creative Commons Attribution License (CC BY). The use, distribution or reproduction in other forums is permitted, provided the original author(s) or licensor are credited and that the original publication in this journal is cited, in accordance with accepted academic practice. No use, distribution or reproduction is permitted which does not comply with these terms. 